\title{
Reasons for adherence and abandonment of physical activity
}

\author{
Larisse Lima Vieira', Vivian de Oliveira², Afonso Antonio Machado³ , Ivan Wallan Tertuliano'
}

\begin{abstract}
Background: The practice of physical activity appropriate to individual conditions and with proper education, brings physical, psychological and social benefits. Objectives: To investigate the main reasons for the adherence and the abandonment of the practice of physical activity. Method: The present work consists of a review study of a propositional type (reflection journal writing) on the reasons of adherence and abandonment to the practice of physical activity. Results: The results showed that among the reasons cited for adherence to physical exercise are the search for: health, aesthetics/physical appearance, socialization, medical order, improvement of physical fitness and quality of life, leisure, well-being, control of corporal weight, competition, pleasure and satisfaction in the practice of exercise, among others. On the other hand, among the reasons for abandonment are: lack of time, laziness, gym distant from the home or work, high cost, influence of the family or media, and work routine. Conclusion: Through the findings, it can be concluded that there is a need for attention by physical education professionals, in addition to the use of efficient strategies to motivate students, with the purpose of getting them to adhere the practice of physical activity and, with that, less people will give up the regular practice of systematized physical activities.
\end{abstract}

Keywords: Physical Activity; Motivation; Exercise; Sport Psychology.

\section{INTRODUCTION}

Commitment is an element that guides and encourages most human activities, embraces an idea, and connects in such a way that the activity becomes permanent, pleasurable, and productive. The commitment of the practitioners of physical activity to the programmed training routine, in the case of physical activity, is called adherence ${ }^{(1)}$.

Thus, adherence can be understood as a set of personal and environmental determinants that allows the free choice of people to adopt a certain recommendation, which strengthens the role of the subject as an active subject who participates and assumes responsibility for his/her training ${ }^{(2)}$. However, adherence does not occur early in the practice because there is a slow process that goes from inactivity to maintenance of physical exercise ${ }^{(3)}$. Costa, Bottcher and Kokubun ${ }^{(4)}$ demonstrate that $50 \%$ of subjects who start a program of systematic physical activity, i.e., of physical exercises, leave it in the first six months of practice.

The practice of physical activity appropriate to individual conditions and with proper education, brings physical, psychological and social benefits in middle age, i.e., the practice of physical activity causes positive health impacts ${ }^{(5,6)}$. As a result of this knowledge, countless people begin daily physical activity. However, getting started does not mean staying and, as already mentioned, countless people give up practicing physical activity a few weeks after the beginning(7).

However, adherence to the practice of physical activity as knowledge should be considered, because knowing the reasons for adherence, the professional can propose activities that lead the practitioners to practice physical activity ${ }^{(8)}$. Thus, it is understood that success in achieving adherence to physical exercises is completely linked to the motivations of its participants. Motivation is considered indispensable for engagement and can be understood by personal and situational factors ${ }^{(9,10)}$.

The reasons for adherence to physical activity practice can be classified in different ways. According to Sherwood e Jeffery ${ }^{(11)}$ the reasons for the practice can be classified in individual and environmental. Individual reasons refer to self-efficacy, history of physical activity, stages of change, body weight, risk factors, diet, stress. On the other hand, environmental reasons refer to social support, time, access to the practice area, exercise characteristics and damages caused by the exercise.

Another classification is proposed by Pitanga ${ }^{(12)}$, in which the reasons for adherence to the practice of physical activity

Corresponding Author: Ivan Wallan Tertuliano - Adress: Estrada de Itapecerica, 5859, Capão Redondo, Cep 05858-001. Telephone: +55 (11) 2128-6000. São Paulo/SP, Brazil. E-mail: ivanwallan@gmail.com

(1) Centro Universitário Adventista de São Paulo (UNASP), São Paulo, São Paulo, Brasil.

Full list of author information is available at the end of the article.

Financial support: The authors declare that there was no financial support.

Submission date 10 May 2018; Acceptance date 03 July 2018; Publication date 11 October 2018 
are classified in: demographic variables (such as age, gender, socioeconomic level and education level), cognitive variables (such as perception of barriers, intention to exercise, mood disorders, self-efficacy, perception of effort and perception about health), environmental variables (such as climate, ease of access and appropriate locations), and social support (such as family and friends). Not least, according to Guedes, Legnani and Legnani ${ }^{(13)}$ psychological attributes related to motivation are essential to take the first step when starting a physical activity, to reach the state of adherence to physical exercise and also help in reducing cases of quitting.

Considering the above, a large number of determinants related to physical activity are observed, demonstrating that studying adherence leads to a better understanding on the motivations of the subjects to include physical exercise in their daily lives. Thus, this study helps the physical education professional to identify these motivations for engaging in physical exercise and to improve their intervention capacity. The objective of this study was to investigate the main reasons for adherence and for the abandonment of physical activity. To reach this objective, the study consists of a review study of a propositional type (reflection journal writing) on the reasons of adherence and abandonment to the practice of physical activity.

\section{METHODS}

In order to meet the aforementioned objective, this study aims to bring a guideline based on the review of classical and contemporary studies, seeking the character of an reflection article, based on the methodological design of a qualitative research on the perspective of documentary analysis ${ }^{(14)}$, since the research aims at the construction of adequate material about the reasons for adherence and abandonment of physical activity practice. In this methodological design, reference was made available through electronic search engines, such as: Google Scholar, Capes, PubMed, Science Research, World Wide Science and Scielo.

The search was given through the terms in Portuguese: Adherence To The Exercise; Adherence To Physical Activity; Motivation; Abandonment From Exercise; Abandonment From Physical Activity. To delimit would leave it smaller, thus, the present research will only have as limiting the total comprehension of the theme and the objective, given the richness of content that a reflection article brings to the reader.

It should be noted that this paper, as a reflection article, did not require the opinion of the Ethics Committee. Thus, there is no submission of approval number to the Ethics Committee.

\section{RESULTS}

\section{Definitions and concepts}

The 21st Century is characterized by the increase of places specially destined to the practice of physical activity. But most of these places are limited to promoting only the practice of physical exercise, not its maintenance ${ }^{(1)}$. New gyms arise with a diversity of physical activities programs, investing more in marketing and bringing many innovations that often are only strategies without continuity. However, after years, gyms, in general, remain a great option for population to improve their general well-being ${ }^{(7)}$.

It is possible to note several types of gyms in all places, with varied publics including men and women of different social classes and age groups, who seek these places for socialization or, in case of adolescents, for substitute their sports activities from school. It is understood that the gyms were created not only for these purposes, but are experiencing issues of sports or physical character, and also of appreciation of the leisure obtained in these places ${ }^{(15)}$.

The goal of any physical activity program is that at the end of it the practitioner has achieved the quality of life, well-being and personal satisfaction inserted in their daily life due to physical activity ${ }^{(1)}$. Thus, it is understood that regular physical activity shows a decrease in the mortality rate for any reason in subjects compared to sedentary subjects ${ }^{(16)}$. Therefore, the search for healthy habits to guarantee a better quality of life comes accompanied by regular and prolonged periods of physical activity (17).

Whatever the reason, any type of physical activity is of extreme importance and necessity for anyone of any age group, being considered great for mental and physical health. The initiative, the first step, the beginning of the practice of physical activity is called the adhesion process, and the continuity of this physical activity for an extended period of time is the adherence process ${ }^{(15)}$. The concept of adherence refers to maintaining the practice of physical exercise for long periods of time. Only at this stage of constant practice that the subject have the possibility of enjoying the physical, psychological and social benefits of exercising, raising their quality of life ${ }^{(1)}$. According to Zamai et al. ${ }^{(7)}$ the adherence is a group of personal and environmental factors and characteristics of physical activity, performed with the aim of guaranteeing their health and well-being.

There are 4 possibilities of behavior of an subject in relation to the adherence to the practice of physical exercise ${ }^{(18)}$. First, the adoption, in which the subject believes in the benefits that physical exercise brings to health and well-being and thus joins a program of physical activities. Secondly, the maintenance, in which the subject is self-motivated, has already established the goals, has no problems regarding the support of family members and has full sense of improvement of the well-being. This subject feels great pleasure in the moment of physical activity and there is no type of inconvenience able to make $\mathrm{him} /$ her not to perform a physical activity.

Third is the disconnection, which occurs with subjects reporting motives such as lack of time, not knowing how to coordinate their tasks, situational factors, who find some kind 
of inconvenience when performing some type of exercise such as shame along with the history of inactivity and also their low physical and motor capacities. Lastly, in the fourth place, the resumption of activity that is accompanied by more flexible goals and objectives, better control of their duties and responsibilities, an improvement in the control of their time for exercise and an increase in self-confidence.

According to the literature, physical activity will bring about visible changes in the life of an subject, leading the person from a sedentary to an active life ${ }^{(9)}$. However, such changes are accompanied by a reasoning about competence regarding expectations about the changes. After being included in the practice of physical activity the person begins to experience what is called the maintenance phase of physical exercise ${ }^{(9)}$. To reach this stage, the practitioner must prioritize the activity that gives more pleasure and fun, and the sense of satisfaction caused by the gain in physical and psychological well-being must always be present ${ }^{(1)}$.

\section{Benefits of Physical Activity}

Physical activity, as long as well performed and conscious, brings numerous benefits to the practitioner ${ }^{(4,16,17)}$. In addition, if practiced in a regular way, physical activity exerts a factor of paramount importance for quality of life, allowing benefits on physical, psychological and social status, regardless of age or gender ${ }^{(19)}$.

Thus, it is understood that the regular practice of physical activity is a strategy to maintain and improve the physical and mental state of an subject, bringing benefits as prevention of functional losses of aging, greatly reducing the risk of diseases ${ }^{(6)}$. According to Mota et al. ${ }^{(20)}$, regular physical activity reduces the risk of various chronic conditions in the elderly, including hypertension, coronary heart disease, metabolic disorder and diabetes. Added to that, Santos and Knijnik(5), state that physically active people can have their biological age reduced in up to 20 years compared to sedentary people which demonstrates the great need to include some type of physical activity in the daily life of the population.

In view of the above, it is observed that an active life avoids obesity, high cholesterol problems, reduces stress and anxiety, brings positive mood changes, regulates adrenaline levels in the blood, improves metabolism and guarantees an improvement in the response of the immune system ${ }^{(21)}$. Still, the psychological benefits overcome the aesthetics because of the amount of time that one is practicing exercise ${ }^{(22)}$.

\section{Motivations for practicing physical activity}

People are highly motivated when they feel valued and competent to perform certain tasks and, in addition, the self-esteem, self-awareness and control, influence the level of motivation.

In the teaching-learning relationship, in any environment, content or moment, motivation is one of the central elements for its successful execution. It can be assumed that without motivation there is no human or animal behavior(23).

The motive is the driving force responsible for initiating and maintaining any activity performed by the human being. It is an internal factor, which initiates, directs and integrates the behavior of a person. Maintenance of the practice will depend on the intensity of the subject. Motivation is the keyword and the fuel of all human action ${ }^{(22)}$. So motivating should be part of the teacher's teaching philosophy. But one must understand well the motivation to use it better ${ }^{(24)}$.

Motivation is characterized as an active and intentional process aimed at a goal, which depends on the interaction of personal (intrinsic) and environmental (extrinsic) factors and the moment of life in which the person is inserted ${ }^{(25)}$. The motivation is related to the affective-cognitive perceptions that the subject has of him/herself and his/her environment, and also motivation is to understand the process that coordinates and gives the direction and the intensity of the effort by the subjects ${ }^{(24)}$, i.e., family members and the place are a potential source of influence and reference. It occurs according to a predetermined goal regardless of the type of activity ${ }^{(9)}$.

Being of the utmost importance the motivation of a subject, one must understand what psychological aspects are related to it. The psychological aspects that influence adherence to physical activity are diverse, but self-confidence and self-motivation can be cited as relevant for adherence ${ }^{(22)}$. These aspects are essential feelings for the constancy in the practice of physical activity, leading the subject easily to the level of maintenance and adherence. Self-confidence can be understood as the belief that you can successfully perform a desired behavior ${ }^{(9)}$. On the other hand, self-motivation is related to personal beliefs about the benefits of physical activity, with little dependence on external incentives such as appearance, health or social recognition ${ }^{(24)}$.

As a source, motivation can be classified as intrinsic and extrinsic. When intrinsically motivated, people perform some kind of activity for the simple pleasure and satisfaction that it causes, consequently these sensations fulfill the psychological needs of autonomy, competence and self-realization ${ }^{(25)}$. When extrinsically motivated, people perform physical activities based on what others find satisfactory or thinking about rewards that the exercise could bring, not on what they actually believe in performing(9).

Intrinsic motivation is considered much more efficient, but the possibilities of extrinsic motivation should not be excluded because one motivation can complete the other ${ }^{(22)}$. So, different motivational orientations may present different cognitive, emotional and behavioral consequences ${ }^{(26)}$.

Therefore, people motivated intrinsically for physical activity should present greater possibility of adherence to their practice than subjects motivated by external dimensions. Theoretically, people encouraged by some type of external 
demand are more likely to abandon the practice and perform it less efficiently than those who practice it with pleasure and autonomy, i.e., people who are intrinsically motivated (27).

It is important to realize that the motives vary and may be unique to each subject in relation to the practice of physical activity. This means that the reasons that motivate one person may not motivate another to practice physical exercise. In addition, the media has a relevant role in adherence to physical activity practice, since it is considered a powerful opinion-shaping device and, thus, a possible motivator for adherence ${ }^{(15)}$.

Added to this, it is noticed that the initiation to a physical activity project must always happen through the accomplishment of moderate activities, that do not come accompanied by competitive factors and always include continuous variations in routine, aiming the pleasure of the practitioner ${ }^{(21)}$. The level of knowledge about the adherence motives, by Physical Education professionals that attend beginners in the practice of physical activity, is considered a differential for the success of the process of adherence to the practice of physical exercises ${ }^{(3,7,9,11)}$. Lastly, Guedes et al. ${ }^{(13)}$ affirm that there is a great sympathy of women with motivations related to esthetics to practice of physical activity. In contrast, the authors point out that men show sympathy with motivations related to challenges and personal competence.

\section{Reasons for abandoning the practice of physical activity}

It is essential to understand that the reasons for abandonment are as important as those of adherence. As reasons for abandoning the practice of physical activity, can be observed the lack of time, lack of energy and lack of motivation ${ }^{(9)}$. Corroborating the mentioned factors, the time spent to get to the place of the practice, the structure for hygiene at the end of the activity, the professional commitments and the spouse health, are also pointed as relevant factors for abandoning the practice of physical activity $^{(8)}$.

Thus, it is observed that the barriers to practice are directly related to free time ${ }^{(5)}$, i.e., priority given to free time should be reviewed, or it will never be used for physical activity. In addition, problems with physical activity programs that do not take into account student preferences and thus do not lead to the enjoyment of physical activity are also relevant to quitting ${ }^{(10)}$. Among other factors of abandonment, Telles et al. ${ }^{(15)}$ pointed out the media, as it shows patterns of beauty, as well as charging them in society, which are often unreachable by most of the population, causing a sense of frustration and, as a consequence, abandonment.

In addition, stress can be another factor of abandonment, because it is related to the uncertainties about the results that physical exercise can cause, or even to the perception of how the individual will be accepted in the environment, and the more uncertainties, the greater the stress and, consequently, abandonment ${ }^{(9)}$. Anxiety is also cited as a factor of neglect, especially when the individual has an anxiety disposition that is called social anxiety, which one feels a great nervousness when perceives the body being evaluated ${ }^{(22)}$.

Added to this, fear of failure, fear of social embarrassment, fear of criticism in their social life, among other fears, may be reasons for quitting ${ }^{(28)}$. Thus, in summary, it is observed that the subject who is willing to practice some kind of systematic physical activity is affected by the emotions, positively or not, so if there is no exchange of good emotions between close friends, co-workers and family members, besides the support so that he/she feels security and confidence in the practice of physical activities, the abandonment will occur ${ }^{(22,28)}$.

\section{CONCLUSIONS}

In view of the above, it can be seen that in health problems are strong factors of adherence to the practice of physical activity ${ }^{(9)}$, demonstrating the need to change the understanding of the role of physical activity in people's lives in periods before adulthood, otherwise, only medical necessity will motivate adherence to physical activity practice. Garay and Oliveira ${ }^{(16)}$ indicate that adherence to the practice of physical activity is difficult and is associated with accession. Besides that, Telles et al. ${ }^{(15)}$ indicate that adherence is greater when there is awareness of the benefits that adherence to physical activity brings in the subject.

Added to that, Nishijuka et al. ${ }^{(29)}$ demonstrate that adherence to the practice of physical activity contributes to the reduction of obesity or overweight. In addition, the authors point out that the Physical Education professional is fundamental for adherence to the practice of physical activity, demonstrating the importance of this professional in the behavioral change of the sedentary population. However, this professional, for a good care and, consequently, to be able to change the behavior of the person about adherence to the practice, needs adequate knowledge and good qualification, otherwise, it may act as a factor of abandonment ${ }^{(30)}$.

However, it is necessary to take into account the free time factor, since the lack of time to practice physical activity is considered as a factor of abandonment ${ }^{(9,22)}$. In view of this, the need for campaigns and awareness-raising activities about the need to include the practice of physical activity in the daily routine is perceived, since only then it will be considered important and no longer occupant of free time.

Such campaigns should occur in childhood, having a greater chance of success ${ }^{(15)}$. Finally, it is understood that practicing physical activity is more than just enrolling in a place of practice, it involves a range of reasons that are essential for each subject and can act effectively in adherence or abandonment of the physical activity practice. 


\section{AUTHORS CONTRIBUTION}

IWT: study design; LLV and VO: data collection; IWT and AAM: critical review of the manuscript. All authors read and approved the final manuscript.

\section{CONFLICT OF INTERESTS}

The authors declare that there was no conflict of interests.

\section{AUTHORS DETAILS}

(2) Centro Universitário FIEO (UNIFIEO), Osasco, São Paulo, Brasil. ${ }^{(3)}$ Universidade Estadual Paulista (UNESP), Rio Claro, São Paulo, Brasil.

\section{REFERENCES}

1. Saba F. Aderência: a prática do exercício físico em academias. Barueri: Manole; 2001.

2. Bento GG, Ferreira EG, Silva FC, Mattana PH, Silva R. Motivação para a prática de atividades físicas e esportivas de crianças: uma revisão sistemática. Rev Bras Atividade Física Saúde. 2017;22(1):13-23.

3. Kopcakova J, Veselska ZD, Geckova AM, Kalman M, van Dijk JP, Reijneveld SA. Do motives to undertake physical activity relate to physical activity in adolescent boys and girls? Int J Environ Res Public Health. 2015;12(7):7656-66.

4. Costa BVD, Bottcher LB, Kokubun E. Aderência a um programa de atividade física e fatores associados. Motriz. 2009;15(1):25-36.

5. Santos SC, Knijnik JD. Motivos de adesão à prática de atividade física na vida adulta intermediária. Rev Mackenzie Educ Física e Esporte. 2006;5(1):23-34.

6. Peixoto ISJ, Liberali R. Aderência e permanência em um programa de atividade física no município de Amargosa - Bahia. Rev Bras Obesidade, Nutr e emagrecimento. 2012;6(34):197-203.

7. Zamai CA, Bavoso D, Rodrigues AA, Barbosa JAS. Motivos de adesão, manutenção e resultados alcançados através da prática de atividades físicas em academias. Resma. 2016;3(2):13-22.

8. Oliveira ÉH. Aderência de praticantes de atividade física: discussão sobre a experiência de alunos de uma academia. [Trabalho de Conclusão de Curso]. Campinas: Universidade Estadual de Campinas. Faculdade de Educação Física; 2011

9. Weinberg RS, Gould D. Fundamentos da psicologia do esporte e do exercício. 6th ed. Porto Alegre: ArtMed; 2017.

10. Liz CM, Crocetta TB, Viana MS, Brandt R, Andrade A. Aderência à prática de exercícios físicos em academias de ginástica. Motriz. 2010;16(1):181-8.

11. Sherwood NE, Jeffery RW. The behavioral determinants of exercise: Implications for physical activity interventions. Annu Rev Nutr. 2000;20:21-44.

12. Pitanga FJG. Epidemiologia da atividade física, exercício físico e saúde 2nd ed. São Paulo: Phorte; 2004.

13. Guedes DP, Legnani RFS, Legnani E. Motivos para a prática de exercício físico em universitários e fatores associados. Rev Bras Educ Física e Esporte. 2012;26(4):679-89.
14. Lakatos EM, Marconi MA. Metodologia Científica. 6th ed. São Paulo: Atlas; 2011.

15. Telles TCB, Araruna LC, Almeida MS, Melo AK. Adesão e aderência ao exercício: um estudo bibliográfico. Rev Bras Psicol do Esporte. 2016;6(1):109-20.

16. Garay LC, Oliveira AP. Aderência e frequência em programas de atividades físicas: a influência de diferentes níveis de aptidão física. Rev Bras Ciência e Mov. 2012;20(1):56-64.

17. Araújo AC. Aderência e permanência de praticantes de exercício físico em academias de praticantes de Iratai, PR. Lect Educ Física y Deport. 2011;16(156).

18. Lopes $P$, Nunomura $M$. Motivação para a prática e permanência na Ginástica Artística de alto nível. Rev Bras Educ Física e Esporte. 2007;21(3):177-87.

19. Carvalho J, Soares J. Envelhecimento e força muscular: breve revisão. Rev Port Ciências do Desporto Port. 2004;4(3):79-93.

20. Mota J, Ribeiro JL, Carvalho J, Matos MG. Atividade física e qualidade de vida associada à saúde em idosos participantes e não participantes em programas regulares de atividade física. Rev Bras Educ Física e Esporte. 2006;20(3):219-25.

21. Torrilla E, Vargas Neto FX. Fatores motivacionais de aderência e permanência nos programas de atividade física em academia. Textura. 2001;(4):81-6.

22. Machado AA. Psicologia do esporte: da educação física escolar ao esporte de alto nível. Rio de Janeiro: Guanabara Koogan; 2006.

23. Gouvêa FC. Motivação e auto-eficácia no esporte e suas interferências no desempenho dos atletas. In: Dobranszky IA, Machado AA, editors. Delineamentos da psicologia do esporte: evolução e aplicação. Campinas: Tecnograf; 2000. p. 19-32.

24. Brandão MRF, Machado AA. Competências psicológicas no esporte infanto-juvenil. 1st ed. Várzea Paulista: Fontoura; 2016.

25. Samulski DM. Psicologia do Esporte: conceitos e novas perspectivas. Barueri: Manole; 2009.

26. Vierling KK, Standage M, Treasure DC. Predicting attitudes and physical activity in an "at-risk" minority youth sample: A test of self-determination theory. Psychol Sport Exerc. 2007;8(5):795-817.

27. Guimarães SÉR, Boruchovitch E. O estilo motivacional do professor e a motivação intrínseca dos estudantes: uma perspectiva da teoria da autodeterminação. Psicol Reflexão e Crítica. 2004;17(2):143-50.

28. Lavoura TN, Machado AA. A vergonha e sua relação com a prática esportiva: um estudo de caso. Motriz. 2007;13(1):64-71.

29. Nishijuka FA, Silva CGS, Duarte CV, Araújo CGS. Aptidão física préparticipação não influencia a aderência a um programa de exercício supervisionado. Arq Bras Cardiol. 2017;109(4):340-7.

30. Bartholomeu Neto J, Pinto JS, Silva JVP, Sales MM, Córdova C, Pereira LA, et al. Motivos do abandono de academias de ginástica por universitários com sobrepeso ou obesidade academics. Rev Bras Ciência e Mov. 2013;21(3):96-104. 